\title{
What Motivates Students Engaging with Public Universities: A Case in Vietnam
}

\author{
Quynh N.H ${ }^{1}$, Hoai N.T ${ }^{2}$,Adang $T^{3}$, Thu N.T.N \\ ${ }^{1234}$ Vietnam- Korea University of Information and Communication Technology, the University of Danang, Danang, Vietnam \\ Email : ${ }^{1}$ nhquynh@vku.udn.vn
}

\begin{abstract}
The fierce competition among educational institutions further affirms the role of maintaining student cohesion as an important strategy for each institution's existence and development. Therefore, the need to better understand this topic for both academics and managers is getting more and more interesting. The relationships between student engagement, and motives have been investigated through several studies in developed countries context, but they have not yet been properly considered for developing countries. An appropriate method - MEC- explored the motivations that force students to engage with the educational institutions in this study. The results show that the five main student engagement motivations include career orientation, financial relevance, memorable emotion, meaningful behaviour, and self-enhancement. This result is expected not only to provide more information for education administrators in determining the factors motivating student engagement with a specific institution but to complement knowledge to the literature foundation of student engagement.
\end{abstract}

Keywords

Career Orientation, Financial Relevance, Mean-end chain, Self-enhancement, Student Engagement Motivation

Article Received: 16th October, 2020; Article Revised: 30th December, 2020; Article Accepted: 08th January, 2021

\section{Introduction}

Education is being valued and seen as a core issue to determine the progress and development of a nation. International exchanges have provided opportunities for students in developing countries to enter the land of modern education. Moreover, more and more universities and colleges have been established, increasing the opportunities of choosing places for students to study. However, with the explosion of educational institutions offering many options for learners, attracting and maintaining the number of students studying at these universities and colleges is becoming increasingly difficult and necessary. As a result, education managers are still seeking and taking steps to continue to attract new students and maintain current students. To do that, it is necessary to enhance the cohesion of students with the training institution. Therefore, educational managers should understand how to strengthen this coherence, what motivations drive students to engage with their school. This is the challenge that educators face to increase student cohesion.

Over the past years, the term "engagement" has been explored and Kahn employed "engagement" concept, the first time, to work in 1990. Later, engagement has been applied widely in other disciplines with a lot of debate about the concept, antecedents, dimensions, motivation, consequences, or structure of engagement in the previous studies.

Engagement concept was used in different contexts, resulting in many "engagement" subterms as customer engagement [1, 2], student engagement [3], social media brand engagement [4],employee engagement[5], consumer engagement [6], a media engagement [7], and civic engagement [8] and has been defined quite flexibly. Student engagement has been considered as investment or commitment [9, 10, 11], participation [12], effortful involvement in learning $[13,14]$ and students' "emotional involvement" and "interest" with school, inclusive of their learning motivation [15].

In addition, reviewing literature shows that the motives that drive engagement are diverse and have different characteristics. For example, [16] revealed that motivation which drive customer engagement relates to their resources, goals, and expectation of value findings, Hollebeek [17] emphasized the importance of perceived cocreated value, Wirtz et al. [18] suggested social and functional motivation for consumer engagement in the virtual brand community, and a study showed that customers' engagement motivation relates to personal consumer 
characteristics (customer ability, customer awareness, perceived role clarity, and willingness of the customers) [19].

Besides, for the research related to engagement motivation, most of them mainly focus on the external dynamics, that is, the values obtained when engaging. However, reality shows that the driving force for the association with a brand/product is often diverse and complex. The motivation for an individual to engage or disengage is not just efforts to achieve social benefits and personal costs, but also influenced by factors of internal values as personal feelings.

In the education context, engagement has been considered as a potential meta-construct [3] and it consistently has been recognized to be a strong predictor of student behaviour and performance in the classrooms [20] and an antecedent to longterm academic achievement and completion of school [21]. In particular, engaged students are more likely to have greater attendance [20], obtain higher grades [22] and better test scores [23], have lower dropout rate [24], and have their teachers willing to supply them with more motivational assistance and support [25]. Also, engaged students indicate more positive attitudes and behaviours (more attention, more interests, and more persistence) than disengaged peers [20]. In contrast, students who manifest low engagement levels are more likely to face long-term adverse consequences including disruptive and absent behaviour in class, and drop out of school [26, 27, 28]. Therefore, engagement has been posited as a crucial indicator and predictor of students' motive and well-being feel within formal learning [29, 30]. In other words, student engagement is generally seen as essential to a long-term commitment of the student to learning goals and social approaches to obtain academic success [3, 31, 32]. Therefore, the development of student engagement process has become a very important task for educators and is recognized as an important tool for universities seeking long-term, sustainable relationships and stimulating positive word-of-mouth intension. Moreover, motivation is an important factor in ensuring a student's academic success and he/she may not make the effort to learn without motivation [30]. Therefore, student motivation is postulated as the driving force which lets a student focus and put effort into learning in order to get successful school outcomes. However, quantities and qualities of motivation are different among students and can change over time depending on the specific learning and teaching context [33, 30]. Moreover, the efficacy of motivations (intrinsic and extrinsic) not only depends on time and context but a certain activity also $[34,35]$. For example, different students can be motivated intrinsically or externally in the same activity [36, 37].

Reviewing previous studies revealed a gap in the discovery of student's motivation for engagement as follows. First, the motivations to engage customers, consumers, civic officials, and students have been explored through many studies from authors around the world, but these studies focus on exploring the engagement motivation of students mainly in developed countries - with advanced and modern education, but are still scarce in the developing countries environment, especially for public universities in Vietnam. It is important to note that learning conditions and target orientation of these two groups are different. Second, the studies of student engagement have been done by exploring its aspects, premises, and consequences rather than focusing on identifying motivation.

To fill this gap, our study focuses on exploring the psychological process of students to determine the multidimensional development of their motivations to engage with a public school in Vietnam. The Means-and-Chain Theory of Gutman [38] and the laddering method [39] were used to analyse, decentralize, and connect the structures discovered from the interview results. This process results in generating valuable psychological understanding of the student's motivation for engagement. By stimulating students to reflect their motivations to engage with schools, research results are expected to supplement valuable insights into the academic research background, but also provide precious content for managers in explaining student attitudes and behaviours to better serve the work of retaining old students and recruiting new students.

\section{Literature Review}

\section{Engagement motivations}

Student engagement (SE) is a useful process that facilitates learning and increases academic success 
$[9,40]$. It is defined as a mental structure that drives the motivation to predict students' perception of positive interpersonal relationships at school in parallel with feelings and cognitive desires to initiate and remain involved in a variety of learning activities and contexts within [3]. Analogically, the degree of student engagement is related to student motivation because it is one of the prerequisites of student engagement in the learning process [30].

A more popular aspect of SE studies is the discovery of the forms of engagement. The previous SE studies show the dominance of three dimensions: behavioural, cognitive, and affective engagement $[41,3]$. Some studies also mention 1 of these 3 aspects in their research [42, 43, 44]. Furthermore, a distinct exploration of the forms of engagement - agentic engagement - also has been suggested by Reeve and Tseng [45]. However, it is important to combine all four subtypes of student engagement when seeking how to understand and enhance students' learning engagement [31]. In each interaction, engagement behaviours are derived from psychological reactions and physical actions are reinforced by motivational constructs [46, 47].

Motivation has been considered as the emotional and cognitive force that initiates, maintains, and directs engagement behaviours, as an intrinsic forming process drawn from the perception, experience, and interpretation of individuals [31]. Also, according to the self-determination theory of Ryan \&Deci [30], the motive is the decisive factor of individuals' behaviours and suggests a need to be competent, autonomous, and relatedness in each individual. 'Competence' pertains to an individual's adapting to the environment, 'autonomy' refers to a one's choosing his behaviours, and 'relatedness' means his/her being close to others. It also includes an inner psychological force leading to action, e.g. engagement behaviours [48]. According to Vivek et al. [16], when individuals are associated with a brand / product, they are often driven by two groups of motives - internal and external. Most users are boosted by a combination of intrinsic motives (fun and altruism), internalized extrinsic (learning, reputation), and entirely extrinsic motivations (payment, career prospects) [49].

\subsubsection{Intrinsic motivations}

Intrinsic motivation has been viewed as engagement in an activity for the enjoyment, interest, challenge, or natural fulfilment of curiosity [50] or to individuals' instinct to succeed, without obvious external incentives [51]. Moreover, according to the goal-orientation theory proposed by Pintrich and Schunk [34], individuals are intrinsically motivated leading to success-oriented people. Internally motivated students have a high degree of learning achievement and a low level of interest and are engaged more than extrinsically motivated students [52, 53].

\subsubsection{Extrinsic motivations}

In contrast to intrinsic motivation, external motivation is triggered by the intention to achieve the desired results or avoid an undesirable one and is combined with external incentives, e.g. monetary compensation or recognition of others [54], stickers or point systems when obtaining successful task performance [55], and obligations or punishments [56]. However, such incentives should only be employed when they are relevant to the student's competencies development or to enhance intrinsic motive [34]. According to Lepper, Iyengar\& Corpus [57], when employing external incentives is improper, it can believe that intrinsic ability is better than rewarded and recognized effort. Therefore, it is essential to clarify how external motivation should be structured to enhance internal motive, for example, reward students who are passionate about seeking new challenges and exploring a different learning experience [57].

\section{Student engagement motivation}

Some studies have been conducted to determine the relationships between students' perceptions of their study motivations and the students' engagement levels that means, to see whether students' motivation levels are related to their class engagement levels [58]. While Hattie [59] proved that self-regulated academic motivation has a positive influence upon student's optimal development, others stated that students might be motivated by ethics of compassion, care, and contribution along with understandable demands for self-satisfaction $[60,61,62]$. Numerous studies suggested that intrinsic and extrinsic motivations drive student engagement. In extrinsic motivation, students manifest specific behaviours due to external incentives, for expecting rewards or satisfying their own ego [51], and even punishing to stimulate and encourage students 
towards the learning success [63]. In other words, incentives have been employed to boost students extrinsically including giving out stickers or candies, publicly recognizing students for successful academic outcomes, or taking away privileges [64].

In contrast, other studies indicate that there is a meaningful relationship between intrinsic motivation and learning achievement $[65,66]$. In particular, an intrinsically motivated student is likely to adjust better personally at the school [67], more likely to have confidence about his/her ability to learn new material and persist with and complete assigned works [68]. Moreover, these students have also lower anxiety levels, higher achievement levels and perceptions of competence, more engagement in learning [52, 53], and employ "more logical informationgathering and decision-making strategies" [69] (p. 2) than extrinsically-motivated students. Intrinsically motivated students often seek out new challenges, explore and learn, extend and experience their capabilities [56]. In other words, students' motivations tend to be more powerful, more easily sustained, and more resilient when they are derived from intrinsic goals rather than from extrinsic ones [53, 70, 56].

Ryan and Deci's Self-Determination Theory (SDT) became well-known within the organizational psychology literature [71]. SDT proposes that some types of extrinsic motivations are weak, whereas some are active and agentic states to external regulation (where a task is attempted to satisfy an external demand), introjected regulation (a task is done for ego enhancement), identification (where the task is valued for itself), and integrated regulation which is the most autonomous kind of extrinsic motivation and exists when external regulations are fully assimilated in a person's self-evaluations and beliefs of their own personal needs.

Integrated motivations, therefore, share qualities with intrinsic motivation, but are still classified as an extrinsic from of motivation. Therefore, students with intrinsic motivation demonstrate authentic engagement; those with extrinsic motivation demonstrate ritual engagement, passive compliance, and retreatism; and students lacking motivation demonstrate engagement at the rebellion level [58].

\section{Means-end chain theory}

Means-end chain (MEC) theory [72, 73] proposed that knowledge of consumer products is organized hierarchically, consisting of different levels of abstraction. Consumers can know products based on their attributes (as the means), the personal consequences of using the product, and the personal values satisfied by them (as the end) [39]. The theory holds that the higher the degree of abstraction, the stronger the relationship with the ego [74]. Consequently, personal consequences become more natural than product attributes themselves and personal values are more natural than individual consequences themselves [39]. According to this theory, the consumer deduces that the product has an attribute (A), which is the most specific. The result of using the product is the consequence $(\mathrm{C})$, which is more 'functional', or more abstract than 'psychosocial' (e.g. admiration from friends). The personal values (V) satisfied by using a product are the highest level of abstraction [38]. Therefore, this theory is often used to find out what drives consumer behaviour.

In the context of engagement, various consequences emanate from the consumption process and the personal values students aim are to be proposed through their engagement with the educational service; Therefore, using the MEC analysis method applied to explore the cognitive relationship between the attributes of student engagement in the learning process, various consequences are suggested through the cohesion and personal values achieved. This takes account of consumer behaviour affected by the pursuit of different goals [75]. One advantage of the MEC method, therefore, is that it takes into account the motivations at different levels, thereby distinguishing between low-order social and functional motivations and the associated higherorder ones [76]. This result will help educational managers understand the motivation of students to engage with educational institutions, so they will have appropriate strategies for maintaining student engagement.

\section{Laddering technique}

Gutman and Reynolds [77] and Reynolds and Gutman [39] developed "Laddering" that refers to an in-depth and one-on-one interviewing technique employed to improve an understanding of how customers translate products' attributes into meaningful links concerning themselves, 
following Means-End Theory [38]. The specific goal of this technique is to define relationships among attributes, consequences, and values. According to Reynolds and Gutman [80], socalled cognitive oriented networks (ladders) represent a combination of factors that serve as a basis for differentiating between products. The distinction at different levels of abstraction, represented by the A-C-V, offers consumers more personal links. The combination of laddering and MEC techniques in the research context will create a hierarchical knowledge value map showing the correlation between $\mathrm{A}, \mathrm{C}$, and $\mathrm{V}$ for a specific product [78]. Specifically, from the results of the interview, the analyst will identify the attributes through the respondents' preferences and choices. Important reasons for the choice provide the results and the value they achieve. The result of this process will create a ladder with full attributes, consequences, and values. The next step is to encode the responses of the interviewee.

\section{Results}

\section{Sampling}

We have selected 60 students studying at public universities in Danang to participate in this study. The selection of many people for such in-depth interviews will provide more opportunities to solve research problems more thoroughly and make the process of creating hierarchical value maps more effective [77]. A convenient sampling technique was selected, which was based on the response of students at the university. The reason for this choice is that the respondent should be able to explain the topic of the interviewer.

\section{Data collection}

Public universities in Vietnam have been chosen as research platforms for a number of reasons. Firstly, the establishment of many domestic universities and the introduction of international universities have opened up many opportunities to choose schools for students, but this has also brought many difficulties for public universities. Second, students have more and more opportunities to study abroad and they also tend to experience cultural differences. Therefore, choosing public schools in Vietnam as the research platform to explore the motivations driving student engagement will bring useful results to educational managers and expand the theoretical background of student engagement.

In-depth interviews were conducted in the schoolyard or at the canteen of universities in June 2020. This interviewing environment creates a sense of safety and comfort for respondents, so they are available to discuss and reveal pointers themselves of educational institutions. Each trained researcher was responsible for interviewing 1 student in about 30-45 ". First, the researcher collected demographic data of the students. Next, they conducted in-depth interviews with each of these students. According to Klenosky\& Saunders [79], the interview process can be enhanced by suggesting that there are no right or wrong answers, and the purpose of the interview is to understand how students see their school as special. Therefore, the results would gather students' motivation to engage in school. In addition to the questions to stimulate the respondent about the importance of the school, the feeling and behaviour of the students towards school are also suggestions to explain the results. Finally, questions that elicit the real value that students gain concluded the interview process. A valuable gift was given to each student after they complete the interview process.

\section{Content analysis \\ Content analysis}

Cavanagh [80] supposed that researchers consider content analysis to be a flexible way to analyse text data. The content analysis presents a group of distinct analytical methods including interpretive, impressive, visual, rigorous, and systematic text analysis [81]. In this study, a content analysis was conducted based on the results of the in-depth interviews that generated attributes, consequences, and values. Next, the synonyms were used for the analysis process, synthesizing the $\mathrm{A}, \mathrm{C}$, and $\mathrm{V}$ to achieve the aggregate level. For the data analysis process to be done in the language of the respondent, manual coding (hand-coding) was used and performed by the programmers. Students' responses were determined to belong to one of the structures $\mathrm{A}, \mathrm{C}$, and $\mathrm{V}$, coded and recorded to calculate the frequency of these structures. The results of the analysis determined a set of 7A (Table 1), 10C (Table 2), 5V (Table 3).

Table 1.

The attributes coding of student engagement motivation 


\begin{tabular}{|c|c|c|c|}
\hline Code & Name & Frequency & Description \\
\hline A01 & Autonomy & 10 & $\begin{array}{l}\text { Engagement with public school calls students to } \\
\text { express their autonomy in learning }\end{array}$ \\
\hline $\mathrm{A} 02$ & Participation in activities & 32 & $\begin{array}{l}\text { Engagement with public school provides opportunities } \\
\text { for the extracurricular activities }\end{array}$ \\
\hline $\mathrm{A} 03$ & Competence & 18 & $\begin{array}{l}\text { Engagement with public school requires students' } \\
\text { efforts }\end{array}$ \\
\hline A04 & Environment concern & 28 & $\begin{array}{l}\text { Engagement with public school expresses concern for } \\
\text { the surrounding environment }\end{array}$ \\
\hline A05 & Low cost & 15 & $\begin{array}{l}\text { Engagement with public school expresses concern for } \\
\text { tuition fee }\end{array}$ \\
\hline A06 & Challenge & 15 & $\begin{array}{l}\text { Engagement with public school provides a challenging } \\
\text { experience }\end{array}$ \\
\hline A07 & Investment in learning & 25 & $\begin{array}{l}\text { Engagement with public school demonstrates } \\
\text { involvement in positive discussion/activities in class }\end{array}$ \\
\hline
\end{tabular}

Table 2.

The consequences coding of student engagement motivation

\begin{tabular}{|l|l|l|l|}
\hline Code & Name & Frequency & Description \\
\hline C01 & Energy in action & 20 & Students volunteer for school activities \\
\hline C02 & Achievement & 18 & Students seek better grade \\
\hline C03 & Positive emotion & 19 & $\begin{array}{l}\text { Students seek good feelings toward their teachers, } \\
\text { peers, school, and the surrounding environment. }\end{array}$ \\
\hline C04 & Perceived success & 12 & Students feel a sense of achievement \\
\hline C05 & Making a contribution & 15 & Students expect to have positive effects on society \\
\hline C06 & Reward & 18 & Students expect to receive social recognition \\
\hline C07 & Safe feeling & 10 & Students expect to be easy in seeking work \\
\hline C08 & Work habit & 25 & Students want to maintain a great habit in working \\
\hline C09 & Saved cost & 24 & Students obtain their cost saving goal \\
\hline C10 & Parents' praise & 24 & $\begin{array}{l}\text { School is expected to bring pride to students' } \\
\text { parents. }\end{array}$ \\
\hline C11 & Social recognition & 18 & Students expect to receive respects from others \\
\hline
\end{tabular}

Table 3.

The values coding of student engagement motivation

\begin{tabular}{|l|l|l|l|}
\hline Code & Name & Frequency & Description \\
\hline V01 & Career orientation & 18 & $\begin{array}{l}\text { Students want a guarantee of future } \\
\text { job opportunities }\end{array}$ \\
\hline V02 & Financial relevance & 15 & Students seek financial relevance \\
\hline V03 & Self-enhancement & 45 & $\begin{array}{l}\text { Students expect to make their image } \\
\text { better and achieve social approval }\end{array}$ \\
\hline V04 & Memorable & 38 & Students seek to live a more \\
\hline
\end{tabular}




\begin{tabular}{|l|l|l|l|}
\hline & emotion & emotional and meaningful life \\
\hline V05 & $\begin{array}{l}\text { Meaningful } \\
\text { behaviours }\end{array}$ & 27 & $\begin{array}{l}\text { Students want to dedicate youth } \\
\text { energy }\end{array}$ \\
\hline
\end{tabular}

\section{Implication Matrix}

The analysis of the contents of the in-depth interview created a set of structures for A, C, and $\mathrm{V}$, however, the total interconnections within each pair of discovered concepts were not shown.
Therefore, it is important to form an implication matrix demonstrating these interconnections. Wherein, laddering procedure with the data from the interview is used as input to the implied matrix. Table 4 reveals the correlations between Attribute-Consequence-Value.

Table 4.

Implication Matrix

\begin{tabular}{|c|c|c|c|c|c|c|c|c|c|c|c|c|c|c|c|c|}
\hline & $\begin{array}{l}\text { C } \\
01\end{array}$ & $\begin{array}{l}\mathbf{C} \\
\mathbf{0} \\
\mathbf{2}\end{array}$ & $\begin{array}{l}\text { C } \\
\mathbf{0 3}\end{array}$ & $\begin{array}{l}\text { C } \\
04\end{array}$ & $\begin{array}{l}\text { C } \\
05\end{array}$ & $\begin{array}{l}\text { C } \\
06\end{array}$ & $\begin{array}{l}\text { C } \\
\text { 0 } \\
7\end{array}$ & $\begin{array}{l}\text { C } \\
\mathbf{0} \\
8\end{array}$ & C 09 & C 10 & C 11 & V01 & V 02 & $\begin{array}{l}\mathbf{V} \\
\mathbf{0 3}\end{array}$ & $\begin{array}{l}V \\
0 \\
4\end{array}$ & $\begin{array}{l}\mathrm{V} \\
0 \\
5\end{array}$ \\
\hline $\begin{array}{l}\text { A0 } \\
1\end{array}$ & & & & & & & & $\begin{array}{l}1 \\
0\end{array}$ & & & & & & & & \\
\hline $\begin{array}{l}\text { A0 } \\
2\end{array}$ & 20 & & & 12 & & & & & & & & & & & & \\
\hline $\begin{array}{l}\text { A0 } \\
3\end{array}$ & & & & & & 18 & & & & & & & & & & \\
\hline $\begin{array}{l}\text { A0 } \\
4\end{array}$ & & & 19 & & & & & & 9 & & & & & & & \\
\hline $\begin{array}{l}\text { A0 } \\
5\end{array}$ & & & & & & & & & 15 & & & & & & & \\
\hline $\begin{array}{l}\text { A0 } \\
6\end{array}$ & & & & & 15 & & & & & & & & & & & \\
\hline $\begin{array}{l}\text { A0 } \\
7\end{array}$ & & & & & & & $\begin{array}{l}1 \\
0\end{array}$ & $\begin{array}{l}1 \\
5\end{array}$ & & & & & & & & \\
\hline $\begin{array}{l}\mathrm{C} 0 \\
1\end{array}$ & & & & & & & & & & & & & & & & $\begin{array}{l}2 \\
0\end{array}$ \\
\hline $\begin{array}{l}\mathrm{C} 0 \\
2\end{array}$ & & & & & & & & & & & & 18 & & & & \\
\hline $\begin{array}{l}\mathrm{C} 0 \\
3 \\
\end{array}$ & & & & & & & & & & & & & & & $\begin{array}{l}1 \\
9 \\
\end{array}$ & \\
\hline $\begin{array}{l}\text { C0 } \\
4\end{array}$ & & & & & & & & & & & & & & 12 & & \\
\hline $\begin{array}{l}\mathrm{C} 0 \\
5\end{array}$ & & & & & & & & & & & & & & 15 & & \\
\hline $\begin{array}{l}\mathrm{C} 0 \\
6\end{array}$ & & & & & & & & & & & 18 & & & & & \\
\hline $\begin{array}{l}\text { C0 } \\
7 \\
\end{array}$ & & & & & & & & & & & & & & & $\begin{array}{l}1 \\
0\end{array}$ & \\
\hline $\begin{array}{l}\mathrm{CO} \\
8\end{array}$ & & $\begin{array}{l}1 \\
8\end{array}$ & & & & & & & & & & & & & & 7 \\
\hline $\begin{array}{l}\text { C0 } \\
9\end{array}$ & & & & & & & & & & 24 & & & & & & \\
\hline $\mathrm{C} 1$ & & & & & & & & & & & & & 15 & & 9 & \\
\hline
\end{tabular}




\begin{tabular}{|l|l|l|l|l|l|l|l|l|l|l|l|l|l|l|l|l|}
\hline 0 & & & & & & & & & & & & & & & & \\
\hline $\begin{array}{l}\mathrm{C} 1 \\
1\end{array}$ & & & & & & 18 & & & & & & & & 18 & & \\
\hline
\end{tabular}

Hierarchical Value Map of the student engagement motivation

In contrast to the implication matrix, Hierarchical Value Map (HVM) presents the common output of a means-end analysis and is a tree-like network. The HVM is considered as a cognitive structure map containing three hierarchical levels including values, attributes, consequences, and linkages.

When estimating the cut-off level, the threshold value is usually chosen as a sample to determine what kind of relationships will be displayed on the map. According to Grunert et al. [82], with a sample of 50 to 60 candidates, a cut-off point will be between 3 and 5. Meanwhile, Reynolds et al. [83] (stated that it is essential to cut-off $5 \%$ of participants. Therefore, in the HVM of the studies, the associations in which the total number of links less than three times $(5 \%$ x60 subjects $=3)$ are not indicated, and any remaining links referred to greater than or equal to three times would be included.

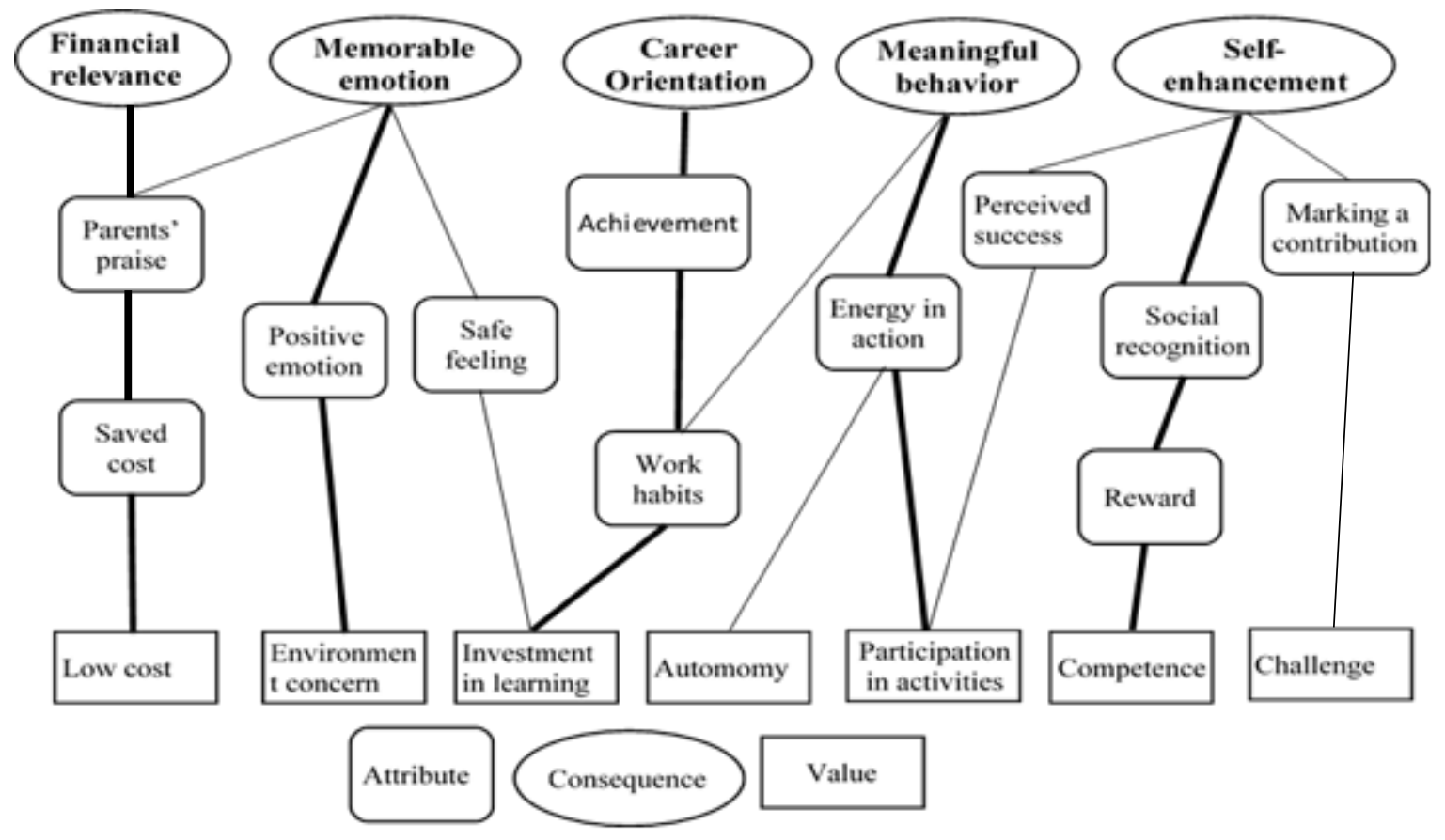

Figure 1. The HVM of student engagement motivation

Figure 1 illustrates five important linkage paths of student engagement motivation and some other sub-paths. The strength of the relationship between the constructs will be expressed through the thickness of the line: the thicker the line proves, the more times the respondent relates to this relationship. These thicker lines will generate the key MECs. The analysis of data from the interviews has formed 5 key MECs providing insights about the engagement motivation of public school students in Vietnam.

These links will be explained as follows:

Investment in learning (A07) - Work habit (C08) - Achievement (CO2) - Career Orientation (V01)
The first important linkage path of student engagement motivation focuses on students who do their best during their studies to get more opportunities for the job application process and continue to study in an international environment. Engaged students with public schools actively participate in the learning process. Through this active learning process, students have made themselves a good habit in studying as well as in other activities. Therefore, many students believe that investment in the study has led them to achieve success in life. Other students said that investment in the study gives them a sense of security for the current results as well as offers 
good opportunities in the future. This means investment in learning helps students to be closer to their career orientation.

Low cost (A01) - Saved cost (C09) - Parents' praise (C10) - Financial relevance (V02)

Low cost is considered to be an essential attribute for engaged students with public schools. These students pay much of their attention to choosing a public school with low tuition fees. They also care about the environment around them. That is, besides the low tuition fees, the cost of their travel, accommodation, and living conditions of the students at the same school is also an equally important issue. Besides, public schools are known for many policies to support students by aiding poor students, disadvantaged students, and needy students with loans. In short, students who engage with schools believe it is their responsibility to reduce the economic burden on their families and to bring joy to their parents. So it is the ultimate core value that financial relevance motivates student engaged with the public universities.

Competence (A06) - Reward (C06) - Social recognition (C11) - Self-enhancement (V03)

The fierce competition among students to get into public schools is an important reason that requires them to have a real capacity. Also, they must make continuous efforts in the learning process and extracurricular activities. This will give students the results they desire. In particular, the effort to demonstrate their competency is also a way to win the important awards of the school. Students will become, therefore, more engaged because they believe that society will recognize their abilities. Logically, the main purpose of engagement is to enhance their self-worth. Since meaning plays an important role in shaping one's purpose, by its nature, having individual meaning and one's pursuit of purpose is said to lead to greater meaning [75]. Self-enhancement can also motivate students to make their image better.

Environment concern (A04) - Positive feeling (C03) - Memorable Emotion (V04)

Public schools are also known for their airy, spacious and beautiful space, adequate facilities to meet students' material needs (e.g. dormitory, canteen) and spiritual needs (gym, cinema room, cafe, club room, etc.). Also, the faculty members are enthusiastic, always encouraging, and showing the spirit of creating a friendly and comfortable learning environment that makes students always feel the care. All of these create a sense of excitement and difference for learners and leave memorable emotions in their minds. Therefore, it is also considered important to increase the meaning of life when an individual is satisfied with their needs for the things they care about.

Participation in activities (A02) - Energy in action (C01) - Meaningful behaviour (V05)

One of the important attributes of engaging with public schools is that students will have more opportunities to participate in social clubs or extracurricular activities. This gives students positive energy, a good sense of their responsibility for the society. Besides, investing in mental effort in learning creates good habits. Combining all of these creates the private meaningful value for public school students, the meaningful behavior.

\section{Discussions}

From the data gathered through the in-depth interview, several qualitative analysis methods were used to analyse them, leading to an interesting result, that is, student engagement with public schools mainly derives from 5 main motivations including career orientation, financial relevance, self-enhancement, memorable emotion, and meaningful behaviour. Most of these motivations demonstrate a clear goal for students when they decide to align with their school. Students want to have more opportunities to continue studying in an international environment or easily find a job (career orientation), to save costs (cost-related motivation), and they also want to be respected by others (self-enhancement). Hars and $\mathrm{Ou}$ [54] proposed that external motivators are separated from the activity itself, such as payment or recognition by others. These motives are considered external ones. In contrast, according to Barry \& King [84], intrinsic motivation refers to the interest, enjoyment, natural satisfaction of curiosity, or fun and selflessness [49]. Thus, expectations of sense of belonging (memorable emotion) and the opportunity to devote their youthful energy to society through volunteering (meaningful behaviour) are seen as inner driving forces to promote living a more emotional and meaningful life.

Students respond distinctly to intrinsic and extrinsic motive and each motive type leads to the distinct engagement form with their learning [85]. Therefore, if educators knowing how to employ intrinsic and extrinsic motive tools and their 
relationships with student engagement in classes, it will help form a positive supportive learning environment for students [9]. In other words, most successfully achieving students are motivated by both internal and external factors, and thus, educators when building strategies attracting student engagement should focus on both types [86]. In short, the analysis of the interview results shows that, while external motivation produces existential values, intrinsic motivation brings sustainable and renewable values for engaged students. This is shown in detail through the following 5 student engagement motives.

\section{Career orientation}

Orientation includes three dimensions of personal performance-approach goal orientation, mastery goal orientation, and personal performanceavoidance goal orientation [87]. These goaloriented aspects are shown to be significantly related to intrinsic and extrinsic motives. Chan, Wong and Lo [88] indicated mastery goal orientation concerning intrinsic motivation and performance-avoidance goal orientation regarding extrinsic motivation. Performance-approach goal orientation is associated with both of these motivation groups [89].

Moreover, the career orientation is to facilitate students in the school-to-work transition process [90]. Second, career orientation explicitly drives students' perception of tasks and decisions to be faced and make [91]. Also, to evoke career competencies among students, it is essential to organize dialogues of concrete experiences, and future orientation with students [92]. Finally, it assists students in presenting their ambitions, qualifications, and abilities, understanding the labour market [93]. Hence, it is essential to recognize that career orientation is an important motivation to drive student engagement.

\section{Financial relevance}

Recent studies hosted by Inceptia have indicated that Bray [94] defines financial stress as the difficulty that an individual or household may have in meeting their basic financial commitments due to a shortage of money. A number of factors contribute to student stress, but very prominent are those related to student finances. From day-today expenditures, to the cost of tuition, to the repayment of loans, students have new financial obligations they have not experienced in the past. Although financial reasons do not appear to be the main driver for non-completion of tertiary study, there is evidence that a young person's financial position can affect their engagement in learning, which in turn affects their current learning outcomes and future study decisions [95]. Students experiencing financial stress are more likely to report less time spent on study commitments [96], which can have a negative impact on their engagement with learning and thus influences their study decisions.

Not out of this trend, Vietnamese students also face financial difficulties during their studies that force them to borrow money. Some studies have identified factors that affect a student's loan decision: fee, cost of living, income of students, accommodation during the period of study, number of people attending school in the student's family [97]. Moreover, by the end of 2017, the outstanding loans of university students accounted for the highest proportion, nearly 59\% of the total number of students who borrowed from the policy program to support students in difficult circumstances [98]. This shows that financial pressure is one of the problems affecting student academic performance. Therefore, a learning environment at a cost suitable to the family's economic condition is one of the criteria that motivates students to choose and associate with the public schools.

\section{Self-enhancement}

Regulatory focus theory generally suggests that self-enhancement orientation, in both conscious and unconscious forms, stems from the possibility of envisioning success in one's attempts at selfpromotion, or the promotion of one's interests [99]. Allport [100] argues that the central target of human existence is self-enhancement. Selfenhancement describes the type of motivation that functions to make individuals feel good about themselves, simultaneously to maintain their selfesteem [100]. Relevant research [101] referring to self-enhancement motivations have indicated certain factors of this motivation, consisting of enhancing personal worth and obtaining social recognition. First, self-enhancement could motivate students to engage actively in all school actions to create a dedication to the school and society [102], thereby enhancing their self-image. Second, the process of engaging in school activities has created a greater connection for students with other students, which can increase a 
sense of self-worth of students and their peers, making them feel that their existence is important and meaningful [103]. Moreover, by connecting themselves with the purpose of cohesion, students are seen as the contributors to the school's success, people's sense of belonging, and selfesteem enhancement, from which they feel valued themselves. Furthermore, from the results of the interview, many students have identified the role of self-enhancement as the benefit value they aim for when connecting with a school. Combining this with previous studies on the role of selfenhancement in a general engagement, it can be suggested that self-enhancement is an important driver of student engagement.

\section{Memorable emotion}

Emotion has proven as one of the most popular dimensions of engagement [104], including student engagement [105]. Cognitive engagement also has become one of the most common subconstructs or types of engagement [3].

In addition, motivation has been defined as a cognitive and emotion force that initiates, sustains, and directs engagement behaviours, as an internalized process of formation drawn from the individual's experiences, perceptions, and interpretations [31]. Intrinsic motivation refers to engaging in an activity for its own sake, for the enjoyment, challenge, interest, natural fulfilment of curiosity [84], or to individuals' instinct to succeed, without obvious external incentives [51]. Füller [49] shows that most users are motivated by intrinsic motives such as fun and altruism. Intrinsically motivated individuals become deeply involved in the present task and experience a sense of pleasure [106] and feel that they can try to make a change in the environment and feel confident that such a change will happen [107]. During the interview, the students showed the belief that exciting and positive emotions during the learning and living process increase their connection with the school, motivating them to be more cohesive with the school. Therefore, the student's memorable emotions are considered as a stimulant factor that motivates their engagement with the school.

\section{Meaningful behaviour}

Meaningful behaviour includes caring for others, fostering peace and peace of mind, encouraging the state of happiness, nurturing creative and exciting situations, and generating prosperity
[108]. While philosophers suggest that two senses of meaning imply meaningful behaviour includes intentions and representation [109], social and self-conscious behaviour have been considered as different aspects of meaningful behaviour, not different kinds [110]. The pragmatic meaning regulation theory proposed that when an individual desires to regain or enhance his sense of meaning, he will be better pleased with potential behavioural strategies that may modify his meaning, and then engage in specific behaviours that maintain or increase his meaningfulness and so such behaviours are called "meaningful behaviour" [111].

Previous research suggest that people often consider behaviours that can fulfil their values more meaningful because the expression and attainment of values enhance a sense of self-worth and individual progression [112]. These achievements are beneficial for meaning in life [113]. Such people are more likely to undertake voluntary service and environmental behaviour [114]. Moreover, Social actions that are taken for the benefit of others will exalt a person's meaning by ameliorating his/her relation with others [115]. Participants with stronger motivations to promote their sense of meaning are likely to show stronger engagement intention [116]. In the educational context, meaningful behaviour is the ideal trigger for meaningful gestures, actions, and messages and it will become a trend for next student generation. Furthermore, the goal of behaviour engagement is to make students more satisfied and also create an aligned, ambitious, and meaningful studying environment that is in line with school rules [117]. Therefore, it can be recognized that meaningful behaviour is an indispensable motive boosting student engagement.

\section{Conclusion}

\section{Theoretical implication}

Although there have been some studies exploring the relationship between student motivation and student engagement, there are still some limitations. Therefore, this study aimed to supplement the theoretical background of student's engagement motivation by providing a few important insights.

First, this is the first study that suggests a student engagement motivation concept and how it is formed in a particular context. To do that, first, a comprehensive review of student engagement 
motivation studies was conducted. Next is the analysis of data from in-depth interviews of students who have been studying in public schools. The results of the study provide a student engagement motivation concept with a multidimensional perspective driven by internal and external motivations. Specifically, student engagement motivation is seen as the force factors for students to engage in their school, considering financial support and the facilitation of educational institutions for them to be recognized by society.

Second, by focusing on student perceptions through in-depth interviews, attributes, consequences, and values related to student engagement structures were identified. This result has led to the formation of five student engagement motives, namely, financial relevance, career orientation, memorable emotion, meaningful behavior, and self-enhancement.

\section{Practical implications}

While increased choice and diversity in schools to study are advantageous to students, it has brought the challenges to educational institutions in maintaining current student populations and attracting new students. Therefore, being aware of the motivations that drive student engagement will provide strategic benefits for educational administrators.

First of all, the results from the in-depth interview showed that students' perceptions of their motivation for engagement differ. This has supported the findings of Marsh [9] that if teachers have a sound understanding of the different types of student motivation possible in any given context, then they are in better position to provide a more conducive learning environment to students that better promotes their learning. At the same time, it also helps educational administrators understand the voice of students, so appropriate strategies can be developed.

\section{Limitations and Future Studies}

Although this is an investigating research that provides motivations for student engagement, it still has some shortcomings.

First, through the Mean-and Chain method, five student engagement motives have been proposed, however, this study utilized only qualitative methods. Therefore, it is necessary to carry out a
Second, meaningful behaviors seem to be becoming a positive trend in the striving goals of many students. Therefore, besides creating a positive learning environment, creating opportunities for students to contribute through extracurricular activities is also an important issue that needs to be addressed.

Third, the increasing unemployment rate, especially after the crisis due to COVID 19, is becoming a financial pressure for many students, especially underprivileged students. Therefore, understanding students' wishes in financial support will bring peace of mind for students to make more academic efforts, increasing their connection with schools which is an important task of educational institutions. Besides, to develop the lifelong learning orientation of students, not only educational institutions strive to promote external motivations such as tuition subsidies and rewards for good academic performance, but also the teacher must evoke the inner motivation of the students [118]. Because money, as a reward, sometimes has detrimental effects on motivation [56]. Therefore, education managers need to deeply understand "why students are attached to their schools", or "why students say: I am proud of being a student of this school, I will choose this school again if I continue to study at higher level". Identifying the right motivation for engagement helps the education manager deliver a meaningful and compelling message to retain old students and attract new ones.

Finally, Savickas found that career orientation explicitly fosters students' awareness of tasks to be faced and decisions to make [93]. The development of educational institutions framework programs, therefore, also needs special attention to meet the interests, qualifications, and ambitions of students, to help them meet the needs of the labor market.

quantitative study to evaluate the reliability and validity of the proposed structures.

Second, the meaningful behavior structure is characterized by subjectiveness and contextually sensitiveness [118]. Differences in student demographics such as gender and family economic conditions have not been explored in this study. Therefore, it is important to investigate further with a larger and more geographically and 
demographically diverse sample to enhance the generality of the proposed model.

Finally, a new proposal for future research is exploring the reverse path to see which engagement will generate positive motivations for student. Values guide one's behavior but the reverse direction is possible at both individualand society-levels [118]

Acknowledgement

The authors would like to express our special thanks to the editor and the anonymous reviewers for their constructive reflections and comments to enable the publication of this paper.

\section{References}

[1] Quynh, N. H. (2019). The moderating influence of brand image on the relationship between customer engagement and customer loyalty. Indian Journal of Marketing, 49(9), 42-56.

[2] Quynh, N. H., Nha, N. P. N., Hoai, N. T., \&Gi-Du, K. (2020). The role of customer engagement in the interrelationship process: moderating effect of customer experience. International Journal of Business Innovation and Research, 23(1), 64-86.

[3] Fredricks, J. A., Blumenfeld, P. C., \& Paris, A. H. (2004). School engagement: Potential of the concept, state of the evidence. Review of educational research, 74(1), 59-109.

[4] Chahal, H., Wirtz, J., \&Verma, A. (2019). Social media brand engagement: Dimensions, drivers and consequences. Journal of Consumer Marketing.

[5] Shahid, A. (2019). The employee engagement framework: high impact drivers and outcomes.Journal of Management Research, 11(2), 45- 54.

[6] Brodie, R. J., Ilic, A., Juric, B., \&Hollebeek, L. (2013). Consumer engagement in a virtual brand community: An exploratory analysis. Journal of business research, 66(1), 105-114.

[7] Habibi, M. R., Laroche, M., \& Richard, M. O. (2014). The roles of brand community and community engagement in building brand trust on social media. Computers in human behavior, 37, 152-161.

[8] Barrett, M., \&Brunton-Smith, I. (2014). Political and civic engagement and participation: Towards an integrative perspective. Journal of Civil Society, 10(1), 5-28.

[9] Marks H.M. (2000), Student engagement in instructional activity: Patterns in the elementary, middle, and high school years. American educational research journal, 37(1), 153-184.

[10] Newmann, F. M. (1992). Student engagement and achievement in American secondary schools. Teachers College Press, 1234 Amsterdam Avenue, New York, NY 10027 (paperback: ISBN-0-8077-3182-X, \$17.95; hardcover: ISBN-0-8077-3183-8, $\$ 38)$.

[11] Tinto, V. (1975). Dropout from higher education: A theoretical synthesis of recent research. Review of educational research, 45(1), 89-125.

[12] Kuh, G. D., Kinzie, J., Buckley, J. A., Bridges, B. K., \& Hayek, J. C. (2007). Major theoretical perspectives on student success in college. Piecing Together the Student Success Puzzle: Research, Propositions, and Recommendations: ASHE Higher Education Report, 32(5), 13-20.

[13] Pekrun R., Linnenbrink-Garcia .L, (2012), Academic emotions and student engagement. In Handbook of research on student engagement, 259-282 Springer, Boston, MA.

[14] Christenson S.L., Reschly A.L, (2012), Eds. Handbook of research on student engagement. Springer Science Business Media.

[15] Vivek, S. D., Beatty, S. E., \& Morgan, R. M. (2012). Customer engagement: Exploring customer relationships beyond purchase. Journal of marketing theory and practice, 20(2), 122-146.

[16] Steinberg. (1996) Beyond the classroom why school reform has failed and what 
parents need to do. New York: Simon Schuster.

[17] Hollebeek, L. D. (2011, June). The customer engagement/co-created value interface: An SD logic perspective. In Proceedings of the 2011 Naples Forum On Service.

[18] Wirtz, B. W., Piehler, R., \&Ullrich, S. (2013). Determinants of social media website attractiveness. Journal of Electronic Commerce Research, 14(1), 11.

[19] Van Doorn, J., Lemon, K. N., Mittal, V., Nass, S., Pick, D., Pirner, P., \&Verhoef, P. C. (2010). Customer engagement behavior: Theoretical foundations and research directions. Journal of service research, 13(3), 253-266.

[20] Klem, A. M., \& Connell, J. P. (2004). Relationships matter: Linking teacher support to student engagement and achievement. Journal of school health, 74, 262-273.

[21] Connell, J. P., Spencer, M. B., \&Aber, J. L. (1994). Educational risk and resilience in African-American youth: Context, self, action, and outcomes in school. Child development, 65(2), 493-506.

[22] Goodenow, C., \& Grady, K. E. (1993). The relationship of school belonging and friends' values to academic motivation among urban adolescent students. The Journal of Experimental Education, 62(1), 60-71.

[23] Willingham, W. W., Pollack, J. M., \& Lewis, C. (2002). Grades and test scores: Accounting for observed differences. Journal of Educational Measurement, 39(1), 1-37.

[24] Ekstrom, R. B. (1986). Who drops out of high school and why? Findings from a national study. Teachers College Record, 87(3), 356-73.

[25] Skinner, E. A., Kindermann, T. A., \&Furrer, C. J. (2009). A motivational perspective on engagement and disaffection: Conceptualization and assessment of children's behavioral and emotional participation in academic activities in the classroom. Educational and psychological measurement,69(3), 493-525.

[26] Rodríguez, L. F., \&Conchas, G. Q. (2009). Preventing truancy and dropout among urban middle school youth: Understanding community-based action from the student's perspective. Education and urban society, 41(2), 216-247.

[27] Archambault, I., Janosz, M., Fallu, J. S., \&Pagani, L. S. (2009). Student engagement and its relationship with early high school dropout. Journal of adolescence, 32(3), 651-670.

[28] Rumberger, R. W. (2010). Education and the reproduction of economic inequality in the United States: An empirical investigation. Economics of Education Review, 29(2), 246-254.

[29] Baumeister, R. F., Vohs, K. D., Nathan DeWall, C., \& Zhang, L. (2007). How emotion shapes behavior: Feedback, anticipation, and reflection, rather than direct causation. Personality and social psychology review, 11(2), 167-203.

[30] Ryan, R. M., \&Deci, E. L. (2009). Promoting self-determined school engagement: Motivation, learning, and well-being. Educational psychology handbook series. Handbook of motivation at school p. 171-195Routledge/Taylor Francis Group.

[31] Reeve, J. (2012). A self-determination theory perspective on student engagement. In Handbook of research on student engagement (pp. 149-172). Springer, Boston, MA.

[32] Lawson, M. A., \& Lawson, H. A. (2013). New conceptual frameworks for student engagement research, policy, and practice. Review of Educational Research, 83(3), 432-479.

[33] Schlechty, P. C. (2001). Shaking up the schoolhouse (Vol. 2). San Francisco: Jossey-Bass.

[34] Pintrich, P. R., \&Schunk, D. H. (2002). Motivation in education: Theory, research, and applications. Prentice Hall. 
[35] Butler, R. (2012). Striving to connect: Extending an achievement goal approach to teacher motivation to include relational goals for teaching. Journal of educational psychology, 104(3), 726.

[36] Areepattamannil, S., Freeman, J. G., \& Klinger, D. A. (2011). Influence of motivation, self-beliefs, and instructional practices on science achievement of adolescents in Canada. Social Psychology of Education, 14(2), 233-259.

[37] Guay, F., Chanal, J., Ratelle, C. F., Marsh, H. W., Larose, S., \&Boivin, M. (2010). Intrinsic, identified, and controlled types of motivation for school subjects in young elementary school children. British Journal of Educational Psychology, 80(4), 711-735.

[38] Gutman, J. (1982). A means-end chain model based on consumer categorization processes. Journal of marketing, 46(2), 6072.

[39] Reynolds, T. J., \&Gutman, J. (1988). Laddering theory, method, analysis, and interpretation. Journal of advertising research, 28(1), 11-31.

[40] Turner, J. C., \& Patrick, H. (2004). Motivational influences on student participation in classroom learning activities. Teachers College Record, 106(9), 1759-1785.

[41] Parsons, J., \& Taylor, L. (2011). Improving student engagement. Current issues in education, 14(1).

[42] Dinsmore, D. L., Alexander, P. A., \&Loughlin, S. M. (2008). Focusing the conceptual lens on metacognition, selfregulation, and self-regulated learning. Educational psychology review, 20(4), 391-409.

[43] Tsai, Y. M., Kunter, M., Lüdtke, O., Trautwein, U., \& Ryan, R. M. (2008). What makes lessons interesting? The role of situational and individual factors in three school subjects. Journal of Educational Psychology, 100(2), 460.

[44] Patrick, H., Ryan, A. M., \& Kaplan, A. (2007). Early adolescents' perceptions of the classroom social environment, motivational beliefs, and engagement. Journal of educational psychology, 99(1), 83.

[45] Reeve, J., \& Tseng, C. M. (2011). Agency as a fourth aspect of students' engagement during learning activities. Contemporary Educational Psychology, 36(4), 257-267.

[46] Skinner, E. A., \&Pitzer, J. R. (2012). Developmental dynamics of student engagement, coping, and everyday resilience. In Handbook of research on student engagement (pp. 21-44). Springer, Boston, MA.

[47] Abraham, S. (2012). Job satisfaction as an antecedent to employee engagement. sies Journal of Management, 8(2).

[48] Füller, J. (2010). Refining virtual cocreation from a consumer perspective. California management review, 52(2), 98-122.

[49] K.M. King, B.J. Brummett, G.D. (2000) King. S. U.S. Patent No. 6,131,766. Patent and Trademark Office Washington, DC: U.S.

[50] Reeve, J., Deci, E. L., \& Ryan, R. M. (2004). Self-determination theory: A dialectical framework for understanding socio-cultural influences on student motivation. Big theories revisited, 4, 3160 .

[51] Wigfield, A., \& Wagner, A. L. (2005). Competence, motivation, and identity development during adolescence. Handbook of competence and motivation, 222-239.

[52] Wigfield, A., \&Eccles, J. S. (2002). Students' motivation during the middle school years. In Improving academic achievement (pp. 159-184). Academic Press.

[53] Alexander Hars, S. O. (2002). Working for free? Motivations for participating in open-source projects. International journal of electronic commerce, 6(3), 25-39.

[54] Williams, W. M., \& Sternberg, R. J. (2002). How parents can maximize 
children's cognitive abilities. Handbook of Parenting Volume 5 Practical Issues in Parenting, 168.

[55] Deci, E. L., \& Ryan, R. M. (1985). The general causality orientations scale: Selfdetermination in personality. Journal of research in personality, 19(2), 109-134.

[56] Corpus, J. H., McClintic-Gilbert, M. S., \&Hayenga, A. O. (2009). Within-year changes in children's intrinsic and extrinsic motivational orientations: Contextual predictors and academic outcomes. Contemporary Educational Psychology, 34(2), 154-166.

[57] Saeed, S., \&Zyngier, D. (2012). How motivation influences student engagement: A qualitative case study. Journal of Education and Learning, 1(2), 252-267.

[58] Swinson, J. (2012). Visable learning for teachers maximizing impact on learning.

[59] Mitra, D. L. (2004). The significance of students: can increasing" student voice" in schools lead to gains in youth development?. Teachers college record, 106, 651-688.

[60] Daniels, E., \&Arapostathis, M. (2005). What do they really want? Student voices and motivation research. Urban Education, 40(1), 34-59.

[61] Heyman, G. D. (2008). Talking about success: Implications for achievement motivation. Journal of Applied Developmental Psychology, 29(5), 361370.

[62] Duchesne, S., \&McMaugh, A. (2018). Educational psychology for learning and teaching. Cengage AU.

[63] Roth, J., Brooks-Gunn, J., Murray, L., \& Foster, W. (1998). Promoting healthy adolescents: Synthesis of youth development program evaluations. Journal of research on Adolescence, 8(4), 423-459.

[64] Lee, J. Q., McInerney, D. M., Liem, G. A. D., \&Ortiga, Y. P. (2010). The relationship between future goals and achievement goal orientations: An intrinsic-extrinsic motivation perspective. Contemporary Educational Psychology, 35(4), 264-279.

[65] Law, W., Elliot, A. J., \& Murayama, K. (2012). Perceived competence moderates the relation between performanceapproach and performance-avoidance goals. Journal of Educational Psychology, 104(3), 806.

[66] Skinner, E., \& Belmont, M. (1991). A longitudinal study of motivation in school: Reciprocal effects of teacher behavior and student engagement. Unpublished manuscript, University of Rochester, Rochester, NY.

[67] Dev, P. C. (1997). Intrinsic motivation and academic achievement: What does their relationship imply for the classroom teacher?. Remedial and special education, 18(1), 12-19.

[68] Lumsden, L. S. (1994). Student Motivation. Research Roundup, 10(3), n3.

[69] Ryan, R. M., \&Deci, E. L. (2001). On happiness and human potentials: A review of research on hedonic and eudaimonic well-being. Annual review of psychology, 52(1), 141-166.

[70] Ambrose, M. L., \&Kulik, C. T. (1999). Old friends, new faces: Motivation research in the 1990s. Journal of management, 25(3), 231-292.

[71] Young, S., \&Feigin, B. (1975). Using the benefit chain for improved strategy formulation. Journal of Marketing, 39(3), 72-74.

[72] Gutman, J. (1997). Means-end chains as goal hierarchies. Psychology \& marketing, 14(6), 545-560.

[73] Olson, J. C., \& Reynolds, T. J. (1983). Understanding consumers' cognitive structures: Implications for advertising strategy. Advertising and consumer psychology, 1, 77-90.

[74] Nguyen, T. H., Ngo, H. Q., Ngo, P. N. N., \& Kang, G. D. (2018). Understanding the motivations influencing ecological boycott participation: An exploratory study in Viet Nam. Sustainability, 10(12), 4786. 
[75] Mooradian, T. A., \&Olver, J. M. (1996). Shopping motives and the five factor model: An integration and preliminary study. Psychological Reports, 78(2), 579592.

[76] Gutman, J., \& Reynolds, T. J. (1979). An investigation of the levels of cognitive abstraction utilized by consumers in product differentiation. Attitude research under the sun, 128-150.

[77] Phillips, J. M., \& Reynolds, T. J. (2009). A hard look at hard laddering. Qualitative Market Research: An International Journal.

[78] Klenosky, D. B., \& Saunders, C. D. (2007). Put me in the zoo! A laddering study of zoo visitor motives. Tourism Review International, 11(3), 317-327.

[79] Cavanagh, S. (1997). Content analysis: concepts, methods and applications. Nurse researcher, 4(3), 5-16.

[80] Rosengren, K. E. (1981). Advances in content analysis (Vol. 9). SAGE Publications, Incorporated.

[81] Grunert, K. G., Beckmann, S. C., \&Sørensen, E. (2001). Means-end chains and laddering: An inventory of problems and an agenda for research. Lawrence Erlbaum Associates Publishers.

[82] Reynolds, T. J., Gengler, C. E., \& Howard, D. J. (1995). A means-end analysis of brand persuasion through advertising. International Journal of research in marketing, 12(3), 257-266.

[83] Barry K., King L., (2000), Beginning Teaching and Beyond 3rd ednKatoomba, NSW: Social Science Press.

[84] Schlechty, P. C. (2011). Engaging students: The next level of working on the work. John Wiley \& Sons.

[85] Strong, R., Silver, H. F., \& Robinson, A. (1995). Strengthening student engagement: What do students want. Educational Leadership, 53(1), 8-12.

[86] Brophy, J. (1998). Failure syndrome students. ERIC Clearinghouse on
Elementary and Early Childhood Education, University of Illinois.

[87] Chan, K. W., Wong, K. Y. A., \& Lo, E. S. C. (2012). Relational analysis of intrinsic motivation, achievement goals, learning strategies and academic achievement for Hong Kong secondary students. The AsiaPacific Education Researcher, 21(2), 230243.

[88] Elliot, A. J., \& Murayama, K. (2008). On the measurement of achievement goals: critique, illustration, and application. Journal of educational psychology, 100(3), 613.

[89] Lent, R. W., \& Worthington, R. L. (1999). Applying career development theories to the school-to-work transition process.

[90] Savickas, M. L. (1999). The transition from school to work: A developmental perspective. The Career Development Quarterly, 47(4), 326-336.

[91] Kuijpers, M. A. C. T., Meijers, F., \& Gundy, C. (2011). The relationship between learning environment and career competencies of students in vocational education. Journal of Vocational Behavior, 78(1), 21-30.

[92] Loan, D. T., \& Van, N. (2015). Career guidance in secondary schools-a literature review and strategic solutions for Vietnamese rural areas. AIJSC, 4(5), 135143.

[93] Bray, J. R. (2001). Hardship in Australia: an analysis of financial stress indicators in the 1998-99 Australian Bureau of Statistics Household Expenditure Survey. FaHCSIA Occasional Paper, (4).

[94] Devlina, M., James, R., \&Griggb, G. (2008). Studying and working: A national study of student finances and student engagement. Tertiary Education and Management, 14(2), 111-122.

[95] Anlezark, A., \& Lim, P. (2011). Does Combining School and Work Affect School and Post-School Outcomes? Longitudinal Surveys of Australian Youth. National Centre for Vocational Education Research 
Ltd. PO Box 8288, Stational Arcade, Adelaide, SA 5000, Australia.

[96] Binh D.T. , T.T. Thuy, (2017), Credit quality for underprivileged students of the Vietnam Bank for Social Policies viewed from students: An empirical study at Hanoi University of Technology, Industry and Trade magazine, 10, 349-357

[97] Higgins, E. T. (1997). Beyond pleasure and pain. American psychologist, 52(12), 1280 .

[98] Allport, F. H. (1937). Teleonomic description in the study of personality. Character \& Personality; A Quarterly for Psychodiagnostic\& Allied Studies.

[99] Klein, J. G., Smith, N. C., \& John, A. (2004). Why we boycott: Consumer motivations for boycott participation. Journal of Marketing, 68(3), 92-109.

[100] Braunsberger, K., \& Buckler, B. (2011). What motivates consumers to participate in boycotts: Lessons from the ongoing Canadian seafood boycott. Journal of Business Research, 64(1), 96-102.

[101] Abosag, I., \& Farah, M. F. (2014). The influence of religiously motivated consumer boycotts on brand image, loyalty and product judgment. European Journal of Marketing.

[102] Stavrova, O., \&Luhmann, M. (2016). Social connectedness as a source and consequence of meaning in life. The Journal of Positive Psychology, 11(5), 470-479.

[103] Claffey, E., \& Brady, M. (2014). A model of consumer engagement in a virtual customer environment. Journal of Customer Behaviour, 13(4), 325-346.

[104] Leventhal, R. C., Franzak, F., Makarem, S., \& Jae, H. (2014). Design benefits, emotional responses, and brand engagement. Journal of Product \& Brand Management.

[105] Walker, C. O., \& Greene, B. A. (2009). The relations between student motivational beliefs and cognitive engagement in high school. The Journal of Educational Research, 102(6), 463-472.

[106] Tyler, K. M., \&Boelter, C. M. (2008). Linking black middle school students' perceptions of teachers' expectations to academic engagement and efficacy. Negro Educational Review, 59(1/2), 27.

[107] Amabile, T. M., \&Gitomer, J. (1984). Children's artistic creativity: Effects of choice in task materials. Personality and Social Psychology Bulletin, 10(2), 209215.

[108] DeCharms, R. (1972). Personal causation training in the schools 1. Journal of Applied Social Psychology, 2(2), 95-113.

[109] Marrero, L. A. (2013). The path to a meaningful purpose: Psychological foundations of logoteleology. iUniverse.

[110] Bunzl, M. (1982). The meaning of" meaningful behavior.". Journal for the Theory of Social Behaviour, 12(1), 21-27.

[111] Rosenow, C. (1928). Meaningful behavior in hypnosis. The American Journal of Psychology, 40(2), 205-235.

[112] Van Tilburg, W. A., \&Igou, E. R. (2011). On boredom and social identity: A pragmatic meaning-regulation approach. Personality and Social Psychology Bulletin, 37(12), 1679-1691.

[113] Steger, M. F., Frazier, P., Oishi, S., \&Kaler, M. (2006). The meaning in life questionnaire: Assessing the presence of and search for meaning in life. Journal of counseling psychology, 53(1), 80.

[114] Scales, P. C., Syvertsen, A. K., Benson, P. L., Roehlkepartain, E. C., \&SesmaJr, A. (2014). Relation of spiritual development to youth health and well-being: Evidence from a global study. Handbook of child well-being, 1101-1135.

[115] Van Tongeren, D. R., Green, J. D., Davis, D. E., Hook, J. N., \& Hulsey, T. L. (2016). Prosociality enhances meaning in life. The Journal of Positive Psychology, 11(3), 225-236. 
[116] Olson, A. L., \& Peterson, R. L. (2015). Student engagement, strategy brief. Lincoln, NE: Student Engagement Project, University of Nebraska-Lincoln and the Nebraska Department of Education.

[117] Schultz, G. F., \&Switzky, H. N. (1990). The Development of Intrinsic Motivation in Students With Learning Problems Suggestions for More Effective Instructional Practice. Preventing School Failure: Alternative Education for Children and Youth, 34(2), 14-20.

[118] Rudnev, M., \&Vauclair, C. M. (2018). The link between personal values and frequency of drinking depends on cultural values: a cross-level interaction approach. Frontiers in psychology, 9, 1379. 